\title{
Editorial
}

\section{Key factors and processes for digital government success}

\author{
Luis F. Luna-Reyes ${ }^{\mathrm{a}, *}$, Sehl Mellouli ${ }^{\mathrm{b}}$ and John C. Bertot ${ }^{\mathrm{c}}$ \\ ${ }^{a}$ Business School, Fundacion Universidad de las Americas Puebla, Puebla, Mexico \\ ${ }^{\mathrm{b}}$ Information Systems Department, Faculty of Business Administration, Université Laval, Quebec, PQ, \\ Canada \\ ${ }^{\mathrm{c}}$ College of Information Studies, University of Maryland, South Wing, College Park, MD, USA
}

\section{Introduction}

Digital government projects and initiatives are complex endeavors. Technology by itself is a source of complexity, as its impacts, benefits and limitations are not always fully understood by project leaders or researchers. This is particularly the case when the implemented technology is not yet widely adopted. Moreover, digital government projects regularly involve the participation of a wide range of diverse stakeholders both in public and private organizations who need to reach agreement on project goals, objectives, and means [2]. Further, project goals and activities are usually constrained by institutional arrangements such as laws and regulations, and several context-related factors such as specific economic situations, demographic conditions, or broader social technology adoption and access $[1,3,4]$.

Given this complexity, it is not uncommon that digital government projects are abandoned before completion or fail delivering the expected benefits. Some experts estimate an $85 \%$ failure rate for digital government projects [11]. In 2009 alone, government spending in technology worldwide was about 428.38 billion US dollars, thus failure rates for these kinds of projects are a major concern [10]. In this way, understanding reasons for project success or failure is an important research and practical problem.

In order to understand success and failure rates, researchers in digital government and more in general, researchers in information systems and information technologies have used two different approaches: a factor approach and a process approach [9]. The factor approach involves the use of correlational statistics to identify the "key success factors", that is to say, the most important variables in determining the success of a project $[5,6]$. Such factors involve variables as technology, organizational, institutional or contextual variables. On the other hand, process approaches, which frequently involve case studies, offer a complementary way to understand project success [9]. From this approach, key variables interact among themselves in a series of processes that evolve dynamically over time, and these processes are as important as the key variables to fully understand success $[7,8]$.

\footnotetext{
${ }^{*}$ Corresponding author: Luis F. Luna-Reyes, Business School, Fundacion Universidad de las Americas Puebla, CS 213 F, Santa Catarina Martir, San Andres Cholula, Puebla, 72820 Mexico. E-mail: luisf.luna@udlap.mx.
} 
Table 1

Papers in the Special Issue

\begin{tabular}{|c|c|c|c|c|}
\hline Authors & Context & Approach & Method & Key factors or processes \\
\hline $\begin{array}{l}\text { Robertson } \\
\text { et al. }\end{array}$ & $\begin{array}{l}\text { Political Discourse in Elec- } \\
\text { tronic Social Networks }\end{array}$ & Process & Content analysis & $\begin{array}{l}\text { Design choices in social networks in- } \\
\text { volving contrasting sentiment, ques- } \\
\text { tions and the role of social browsers in } \\
\text { reflecting social affect and intention. }\end{array}$ \\
\hline Bertot et al. & $\begin{array}{l}\text { Partnerships to } \\
\text { Deliver Digital } \\
\text { Government Services }\end{array}$ & $\begin{array}{l}\text { Factor } \\
\text { and } \\
\text { process }\end{array}$ & Multi-method & $\begin{array}{l}\text { Having a support infrastructure, under- } \\
\text { standing mutual benefits, true partner } \\
\text { feedback and collaboration in technical } \\
\text { support and training. }\end{array}$ \\
\hline $\begin{array}{l}\text { Sawyer } \\
\text { et al. }\end{array}$ & $\begin{array}{l}\text { Enterprise Architectures in } \\
\text { Public Safety Networks }\end{array}$ & Process & $\begin{array}{l}\text { Fuzzy set qualitative } \\
\text { comparative analysis }\end{array}$ & $\begin{array}{l}\text { Several patterns to success involving } \\
\text { focus on system-level objectives, data- } \\
\text { related objectives, and diversity of pro- } \\
\text { cesses, data, applications and devices. }\end{array}$ \\
\hline Daou et al. & $\begin{array}{l}\text { E-Government services in } \\
\text { outlying regions }\end{array}$ & Factor & $\begin{array}{l}\text { Interviews and qualita- } \\
\text { tive data analysis }\end{array}$ & $\begin{array}{l}\text { Key factors to adoption of e-govern- } \\
\text { ment services in four basic dimensions: } \\
\text { Technology, Organization, Finance and } \\
\text { Digital Divide. }\end{array}$ \\
\hline Luna et al. & State Portals & Factor & Data envelop analysis & $\begin{array}{l}\text { Contextual, organizational and institu- } \\
\text { tional factors as elements to better un- } \\
\text { derstand performance in Internet State } \\
\text { Portals. }\end{array}$ \\
\hline
\end{tabular}

This special issue includes a collection of five papers presented at the 13th Annual Conference on Digital Government Research dg.o 2012, all of them dealing with understanding success of digital government projects, using a variety of methods, and taking either a factor or a process perspective. Table 1 shows the richness of this sample of papers, highlighting some key dimensions. We believe that the papers in this special issue contribute to the development of our understanding of digital government success at least in three dimensions: (1) in terms of methodological approaches, (2) in terms of the richness of contexts, and (3) in terms of the key factors and processes identified in each paper.

The methodological approaches and contexts of application in the papers provides a unique contribution in terms of ways to understand success. Robertson and his colleagues, for example, collect text data from Facebook, and use content analysis to understand patterns in the political discourse of social networks. Bertot and his colleagues, on the other hand, combine data from a survey, case studies and in-depth interviews to study success factors in developing successful partnerships to deliver digital government services through Public Libraries. Using survey data, Sawyer and his colleagues apply Fuzzy Set Qualitative Comparative Analysis to explore success patterns to improve performance through technology in Public Safety Networks. In the fourth paper, Daou and his colleagues use interviews to identify adoption factors of e-government services by governments in outlying regions. Finally, Luna and her colleagues apply Data Envelop Analysis to secondary data to identify ways in which key inputs and success factors impact on the performance of state government portals in Mexico.

Finally, the papers in the special issue identify interesting factors related to organizational, institutional, contextual and design variables that contribute to better understand success in digital government projects. The first paper by Robertson et al. identifies the role of social browsers in reflecting to an on-line community on social affect and social intention by making questions, requests and contrasting sentiments to improve political discourse during an election process. In the second paper, the contribution is twofold. On the one hand, they identify important factors contributing to the use of libraries to access digital government services, such as the lack of technical skills, understanding of civics, trust 
in government or digital literacy. Additionally, they identify key success factors in partnerships among libraries and other local organizations to deliver such services. These factors include the understanding of a mutual benefit, the existence of a support infrastructure and collaboration in support and training.

Starting with a simplified model of Information and Communication Technologies Architecture, Sawyer et al. identify patterns to success in police- and court-oriented public safety networks. Although there are unique combinations of these elements, configurations involving a diversity of devices and applications or those involving a focus on strategy and business processes constitute patterns to success in police-oriented networks. As we mentioned before, Daou and his colleagues identified important factors to the adoption of digital government services in outlying regions, which they grouped in four dimensions, technology, organization, finance and digital divide. Technology know-how, resistance to change, and social and demographic conditions constitute examples of these factors. Finally, contextual factors such as internet or computer penetration, state infrastructure, organizational and institutional factors grouped into efficiency and competitiveness indexes are proposed by Luna and her colleagues as elements to better understand success in developing successful government portals at the State level.

We believe that the set of papers presented in this special issue constitute a valuable contribution to the understanding of digital government success. In the following paragraphs, we briefly describe each of the papers in this special issue.

\section{Papers in the Special Issue}

The first paper in the special issue, by Robertson and his colleagues, explores the evolution of the political discourse in the social networks of the two candidates to governor in the state of California. They apply content analysis techniques to the news feeds from the Facebook pages of both candidates. They confirm two patterns found in previous studies, suggesting that communities build identity in the first stages of the election process, and work towards differentiate from the opponent community in the second stage of the process. The first stage is characterized by the use of first and second person pronouns, and the second one by the use of the third person. Another difference between these two stages is the use of positive sentiments during the identity formation stage, moving to more negative ones in the differentiation stage. They found that the community around the winner of the elections came back to the use of positive, first-person comments during the elections. Analyzing the type of interactions with each candidate, the authors hypothesize that social browsers that provide feedback to the community may play a key role in the formation of the discourse in the community.

Through case studies and survey data, the second paper by Bertot et al. explores the key roles that public libraries play in successful e-government use, adoption, and transformation. More specifically, the research demonstrates that through collaborations and partnerships, government agencies and public libraries can work to create socially innovative approaches to e-government that foster a comprehensive approach that accounts for a number of user divides - digital, literacy, language - while simultaneously creating innovative and more comprehensive approaches to digital government services. The study identifies several partnership success factors, including: 1) Both the library and the agency saw mutual benefit to entering into a partnership designed to provide collaborative e-government services; 2) Agencies viewed the partnership as a way through which to extend e-government services to the intended service recipients through libraries; 3) Agencies considered librarian feedback regarding e-government service design and delivery; and 4) Agencies were willing to help librarians better understand the e-government services, resources, and technologies. This leveraging of government and library resources created a more comprehensive and community-based approach to e-government. 
In the third paper, Sawyer et al. use survey data to understand characteristics of Information and Communication Technology Architectures (ICTA) to succeed in building successful police- and courtoriented Public Safety Networks (PSNs). Their analysis starts by identifying ICTA components from the literature, resulting on a simplified model of six components: (1) focus on system-level objectives, (2) focus on data-related objectives, (3) diversity of business processes, (4) diversity of application types, (5) diversity of data types, and (6) diversity of device types. They used then this characteristics and fuzzy set qualitative comparison analysis to find patterns to success in building PSNs. The analysis shows that there is no single pattern to success. Five patterns of ICTA are associated with successful Court PSNs, and three patterns are related to successful police PSNs. Each of these patterns involves emphasis on two or more architectural components. For example, 14 successful Court PSNs emphasize on data, data-related objectives and a diversity of business processes, making this pattern one of those patterns to success. It is important to note that combinations included all six components of ICTA, making hard to identify one of them that could clearly be part of a successful strategy.

The fourth paper, by Daou et al, discusses e-government services adoption in outlying regions. The paper analyzes the needs and barriers to e-government through the lenses of managers in these regions. To this end, an exploratory research is undertaken in four outlying regions of Quebec, Canada. The authors met with 36 managers in these regions who pointed to four major categories of concern for the development of online services: organizational; financial; technological; and digital divide. The authors show that these barriers must be addressed if governments hope to increase efficiency of online services in outlying regions. The authors concluded that no social appropriation of online services can be achieved, if civil servants and employees of public and parapublic organizations in outlying regions do not adopt e-government technologies first.

In the final paper of the special issue, Luna and her colleagues use secondary data to explore ways in which contextual, organizational and institutional factors modify the assessment of success of Internet State Portals in Mexico. The basic assumption is that part of the variation of the measure of success among State portals is explained by these contextual, institutional and organizational factors, which may be considered inputs into the portal development process. Comparing the levels of functionality without taking into consideration these differences among the States may lead to unfair assessments of each of them. In fact, Data Envelop Analysis applied to these data suggests that some of the States that are underperformers are as efficient as some of the usual leaders when considering the set of inputs found by the authors. The work suggests then that any evaluation of success may include the consideration of the main inputs into the process to better capture the effort and efficiency of project managers.

\section{References}

[1] J.C. Bertot, P.T. Jaeger and D. Hansen, The impact of polices on government social media usage: Issues, challenges, and recommendations, Government Information Quarterly 29(1) (2012), 30-40.

[2] S.S. Dawes, A.M. Cresswell and T.A. Pardo, From "Need to Know" to "Need to Share": Tangled Problems, Information Boundaries, and the Building of Public Sector Knowledge Networks, Public Administration Review 69(3) (2009), 392402.

[3] J. Fountain, Building the Virtual State: Information Technology and Institutional Change, The Brookings Institution, 2001.

[4] J.R. Gil-Garcia, Enacting Electronic Government Success: An Integrative Study of Government-wide Websites, Organizational Capabilities, and Institutions, Springer, 2012.

[5] J.R. Gil-Garcia and T.A. Pardo, E-government success factors: Mapping practical tools to theoretical foundations, Government Information Quarterly 22(2) (Apr. 2005), 187-216.

[6] K.R.T. Larsen, A Taxonomy of Antecedents of Information Systems Success: Variable Analysis Studies, Journal of Management Information Systems 20(2) (Fall. 2003), 169-246. 
[7] L.F. Luna-Reyes and J.R. Gil-Garcia, Using institutional theory and dynamic simulation to understand complex eGovernment phenomena, Government Information Quarterly 28(3) (Jul. 2011), 329-345.

[8] L.F. Luna-Reyes, J. Zhang, J.R. Gil-Garcia and A.M. Cresswell, Information systems development as emergent sociotechnical change: A practice approach, European Journal of Information Systems 14(1) (Mar. 2005), 93-105.

[9] M. Newman and D. Robey, A Social Process Model of User-Analyst Relationships, MIS Quarterly 16(2) (1992), 249266.

[10] A. Ojo, T. Janowski and E. Estevez, Whole-of-government approach to information technology strategy management: Building a sustainable collaborative technology environment in government, Information Polity: The International Journal of Government and Democracy in the Information Age 16(3) (Sep. 2011), 233-250.

[11] Success and Failure Rates of eGovernment in Developing/Transitional Countries: Overview, 2003. www.egov4dev.org/ sfoverview.htm. 